\title{
KECERNAAN BAHAN KERING DAN BAHAN ORGANIK PAKAN YANG MENDAPAT SUPLEMENTASI UREA MOLLASES MULTINUTRIENT BLOK (UMMB) DARI BEBERAPA JENIS LIMBAH PERTANIAN DAN RUMPUT LAPANG
}

\author{
Suprianto Belo, Ronny Tuturoong*, Kartini Maaruf
}

Fakultas Peternakan Universitas Sam Ratulangi Manado. 95115

\begin{abstract}
ABSTRAK
Hijauan yang umum di berikan untuk ruminansia berupa rumput-rumputan yang berasal dari padang pengembalaan atau kebun rumput, pematang, serta pinggiran jalan. Selain itu, masih ada sumber pakan ternak yang belum di manfaatkan secara optimal yaitu limbah pertanian. Beberapa kendala pemanfaatan limbah pertanian sebagai pakan ternak disebabkan karena pada umumnya limbah pertanian memiliki kualitas rendah dengan kandungan serat yang tinggi, rendah protein, dan kecernaannya rendah sehingga akibatnya apa bila digunakan sebagai pakan basal dibutuhkan penambahan bahan pakan lain yang memiliki kualitas yang baik untuk memenuhi kebutuhan ternak dalam meningkatkan produktivitasnya. Salah satu cara untuk mengoptimalkan nilai nutrisi limbah pertanian adalah dengan pemberian suplemen pakan seperti urea molasses multinutrient block (UMMB).

Penelitian telah dilaksanakan di Desa Tonsewer, Kecamatan Tompaso Barat selama 40 hari mulai dari November 2016 sampai dengan Desember 2016. Ternak yang digunakan pada penelitian ini adalah sapi PO jantan, umur 12 - 18 bulan sebanyak 4 ekor dengan berat badan \pm 100 $\mathrm{kg}$ dan pakan yang diberikan adalah rumput lapang (RL), jerami jagung (JJ), jerami padi(JP), dan jerami kacang tanah (JKT), serta UMMB sebagai pakan suplemen. Penelitian ini menggunakan
\end{abstract}

*Korespondensi (corresponding author):

Email: ronny.tuturoong@gmail.com eksperimen Bujur Sangkar Latin (Latin Square Design) 4 x 4, dengan 4 ekor ternak dan 4 macam perlakuan. Hasil penelitian ini menunjukkan bahwa analisis keragaman menunjukkan bahwa perlakuan memberikan pengaruh yang berbeda nyata $(\mathrm{P}<0,05)$ terhadap konsumsi dan kecernaan BK dan BO. Kecernaan BK pakan perlakuan berturut-turut adalah R1 $(67,51 \%), \mathrm{R} 2(68,57 \%), \mathrm{R} 3(63,51 \%)$ dan R4 (72,78\%) dan kecernaan BO adalah R1 (72,78\%), R2 (74,22\%), R3 (67,33\%), dan R4 $(67,33 \%)$.

Kata kunci : limbah pertanian, UMMB, kecernaan, BK, BO dan sapi PO

\section{ABSTRACT}

DRIED MATERIALS AND ORGANIC MATERIALS WHICH ARE SUPPLYING UREA MOLLASES MULTINUTRIENT BLOCKS OF (UMMB) FROM SEVERAL AGRICULTURAL WASTE AND EQUIPMENT GRASS. The common forages are given for ruminants in the form of grasses coming from pastures or lawns, bunds, and roadside. In addition, there are still sources of animal feed that has not been utilized optimally the agricultural waste. Some obstacles to the utilization of agricultural waste as animal feed is caused by the generally low quality of agricultural waste with high fiber content, low protein, and low digestibility so that when it is used as a basal feed it is necessary to add other feed ingredien

ts that have good quality to meet the needs livestock in improving productivity. One way to optimize the nutritional value of 
agricultural waste is by providing feed supplements such as urea molasses multinutrient block (UMMB).

The research was conducted in Tonsewer Village, Tompaso Barat District for 40 days starting from November 2016 until December 2016. The animals used in this study were male PO cattle, aged 12 - 18 months as many as 4 tails with weight \pm $100 \mathrm{~kg}$ and feed given is field grass (RL), corn straw (JJ), rice straw (JP), and groundnut straw (JKT), and UMMB as a supplement feed. This study used a $4 \times 4$ Latin Square Design experiment with 4 cattle and 4 treatments. The results of this study indicate that the diversity analysis showed that the treatment had significantly different effect $(\mathrm{P}<0.05)$ on the consumption and digestibility of $\mathrm{BK}$ and BO. The digestibility of feedstuff DM was R1 (67,51\%), R2 (68,57\%), R3 (63,51\%) and R4 (72,78\%) and $\mathrm{BO}$ digestibility was R1 (72,78\%), R2 (74.22\%), R3 (67.33\%), and R4 (67.33\%).

Key words: crop residues, UMMB, DM, $\mathrm{OM}$ digestibility and ongole crossbred cattle

\section{PENDAHULUAN}

\section{Limbah pertanian di Sulawesi}

Utara cukup melimpah, tetapi belum dimanfaatkan secara optimal sebagai pakan ruminansia. Limbah pertanian itu antara lain berupa jerami padi, jagung, dan kacang tanah. Beberapa kendala pemanfaatan limbah pertanian sebagai pakan ternak disebabkan karena pada umumnya limbah pertanian memiliki kualitas rendah dengan kandungan serat yang tinggi, rendah protein dan kecernaannya rendah; sehingga akibatnya apabila digunakan sebagai pakan basal dibutuhkan penambahan bahan.yang memiliki kualitas yang baik untuk memenuhi kebutuhan ternak dalam meningkatkan produktivitasnya. Salah satu cara untuk mengoptimalkan nilai nutrisi limbah pertanian adalah dengan pemberian suplemen pakan seperti urea molasses multinutrient block (UMMB).

Hasil penelitian Maaruf dan Paputungan (2017) menunjukkan bahwa jerami padi mengandung OM 76-79\%, NDF $78,3-84,9 \%$, ADF 57,1-51,5\%, hemiselulosa $21,3-33,6 \%$, selulosa 30,8 31,6\%, lignin 5,4-5.7\% dan PK 6,2-7,9\%. Winugroho et al. (1983) melaporkan bahwa kecernaan BK dan BO jerami padi berturut-turut berkisar antara $34-52 \%$ dan $42-59 \%$.

Kandungan nutrisi jerami jagung: OM 91,4-92,0\%, NDF 62, 9-65,8\%, ADF $37,3-39,0 \%$, hemiselulosa 25, 6-26, 8\%, selulosa 30, 7-33, 7\%, lignin 2, 7-3,2\% dan PK 4, 6-4, 8\% (Maaruf dan Paputungan, 2017); serta jerami kacang tanah mengandung PK 12,90\%, SK $26,36 \%$, bahan ekstrak tanpa nitrogen (BETN) 44,13\%, abu 14,14\%, ADF 43,67\%, NDF 50,84\% dan lignin 7,28\% (Maaruf, 1986).

Penggunaan UMMB pada ternak sapi potong terbukti dapat meningkatkan konsumsi pakan dan pertambahan bobot 
badan (Preston dan Leng, 1987). Garg dan Gupta (1992) melaporkan bahwa suplementasi UMMB meningkatkan kecernaan BK, BO dan PK jerami gandum pada sapi. Selanjutnya, suplemen UMMB pada jerami jagung dapat meningkatkan kecernaan protein dan energi. Chuzaemi $e t$ al. (1989) melaporkan bahwa pemberian UMMB dapat meningkatkan kecernaan BK dan BO jerami padi pada kambing.

\section{MATERI DAN METODE PENELITIAN}

Penelitian ini telah dilaksanakan di sentra peternakan sapi PO yang ada di Desa Tonsewer, Kecamatan Tompaso Barat selama 40 hari mulai dari November 2016 sampai dengan Desember 2016. Ternak yang digunakan pada penelitian ini adalah sapi PO jantan, umur 12 - 18 bulan sebanyak empat ekor ternak dengan berat badan $\pm 100 \mathrm{~kg}$.

\section{Pakan percobaan.}

Pakan yang diberikan adalah rumput lapang, jerami jagung, jerami padi, dan jerami kacang tanah, serta UMMB sebagai pakan suplemen. Penelitian ini menggunakan eksperimen Bujur Sangkar Latin (Latin Square Design) 4 x 4, dengan 4 ekor ternak dan 4 macam perlakuan.Perlakuan yang akan diterapkan adalah sebagai berikut:

$$
\begin{aligned}
& \text { R1: Rumput Lapang + UMMB } \\
& \text { R2: Jerami Jagung + UMMB } \\
& \text { R3: Jerami padi + UMMB } \\
& \text { R4: Jerami Kacang Tanah + UMMB } \\
& \text { Untuk melihat pengaruh dari } \\
& \text { masing-masing perlakuan terhadap setiap }
\end{aligned}
$$

Tabel 1.Komposisi nutrien dari bahan pakan penelitian (dasar bahan kering)

\begin{tabular}{llcccc}
\hline \multicolumn{1}{c}{ Nutrien } & $\begin{array}{c}\text { Rumput } \\
\text { Lapang }\end{array}$ & Jerami Jagung & $\begin{array}{c}\text { Jerami } \\
\text { Padi }\end{array}$ & $\begin{array}{c}\text { Jerami Kacang } \\
\text { Tanah }\end{array}$ & UMMB \\
\cline { 2 - 6 } & R1(\%) & R2(\%) & R3(\%) & R4(\%) \\
\hline Protein Kasar & 15,14 & 12,93 & 4,16 & 14,04 & 24,50 \\
Lignin & 6,99 & 9,85 & 10,23 & 5,30 & 0.72 \\
Silika & 3,62 & 4,95 & 5,27 & 0,77 & 1.08 \\
NDF & 74,46 & 68,78 & 75,88 & 48,73 & 9.6 \\
ADF & 42,93 & 42,36 & 52,18 & 31,28 & 5,4 \\
BK & 22,26 & 43,23 & 44,83 & 44,97 & 76,50 \\
BO & 92.019 & 91.94 & 77.92 & 92.15 & 76,30
\end{tabular}

Sumber: Hasil Analisis Laboratorium Ilmu dan Teknologi Pakan Fakultas Peternakan IPB, Bogor 2016. 
variabel yang diamati (konsumsi dan kecernaan BK dan BO). Kandungan BKdan BO sampel dianalisis sesuai petunjuk AOAC (1990). Data hasil penelitian dianalisis dengan analisis keragaman yang sesuai denagn rancangan percobaan yang digunakan. Uji orthogonal kontras digunakan untuk melihat membandingkan pengaruh antar perlakuan atau antar kelompok perlakuan dari variabel yang diamati.

Uji orthogonal kontras yang digunakan adalah :

$\mathrm{C} 1$ : R1 vs R2 + R3 + R4 yaitu membandingkan antara rumput lapang dengan jerami jagung + jerami padi + jerami kacang tanah

C2 : R2 + R3 vs R4 yaitu membandingkan antara jerami jagung + jerami padi dibandingkan dengan jerami kacang tanah atau membandingkan antara jerami rumput-rumputan dengan jerami legum

C3 :R2 vs R3 yaitu membandingkan antara jerami jagung dengan jerami padi atau dengan kata lain membandingkan antara dua macam jerami rumputrumputan.

\section{HASIL DAN PEMBAHASAN}

Rataan konsumsi BK pakan (Tabel 2) perlakuan selama penelitian berada pada kisaran antara 2567,98 - 2782,56 gram/ekor/hari atau berkisar antara 2,6$2,8 \%$ berat badan. Hasil ini masih sesuai dengan rekomendasi NRC yang menyatakan bahwa konsumsi bahan kering pada ternak sapi berkisar antara $2-4 \%$ dari berat badan, tetapi lebih tinggi

Tabel 2. Konsumsi dan kercernaan BK dan BO selama penelitian.

\begin{tabular}{|c|c|c|c|c|c|c|c|}
\hline & \multirow[t]{2}{*}{$\mathrm{RL}$} & \multirow[t]{2}{*}{ JG } & \multirow[t]{2}{*}{$\mathrm{JP}$} & \multirow[t]{2}{*}{ JKT } & \multicolumn{3}{|c|}{ Kontras } \\
\hline & & & & & $\mathrm{C} 1$ & $\mathrm{C} 2$ & $\mathrm{C} 3$ \\
\hline $\begin{array}{l}\text { Konsumsi BK } \\
\text { gram/ekor/hari }\end{array}$ & 2782,56 & 2658,17 & 2594,87 & 2567,98 & * & ns & ns \\
\hline $\begin{array}{l}\text { Konsumsi BO } \\
\text { gram/ekor/hari }\end{array}$ & 2769.52 & 2595,812 & 3998333981 & 29953183252 & 28 & 1325 & $226 \% 983$ \\
\hline $\begin{array}{c}\text { Kecernaan BK } \\
(\%)\end{array}$ & 67,51 & 68,57 & 63,51 & 72,78 & $\mathrm{~ns}$ & $*$ & * \\
\hline $\begin{array}{l}\text { Kecernaan BO } \\
(\%)\end{array}$ & 72,71 & 74,22 & 67,33 & 78,91 & ns & * & $*$ \\
\hline
\end{tabular}


Keterangan :

$\mathrm{C}_{1}=$ Orthogonal kontras antara RL vs JG $+\mathrm{JP}+\mathrm{JKT}$

$\mathrm{C}_{2}=$ Orthogonal kontras antara JG $+\mathrm{JP}$ vs JKT (jerami rumput-rumputan vs jerami legum)

$\mathrm{C}_{3}=$ Orthogonal kontras antara jerami jagung vs jerami padi (antar jerami rumput-rumputan)

ns : tidak berbeda nyata $(\mathrm{P}>0,05)$, dan $*$ : berbeda nyata $(\mathrm{P}<0.05)$

dibanding dengan penelitian Utomo et al. (1998) yang melaporkan bahwa konsusi BK jerami padi suplementasi sebesar $2 \%$ dari berat badan. Analisis keragaman menunjukkan bahwa perlakuan memberikan pengaruh yang berbeda nyata $(\mathrm{P}<0,05)$ terhadap konsumsi BK dan BO. Uji lanjut orthogonal kontras yang dilakukan adalah: C1. Membandingkan antara konsumsi BK dan BO rumput lapang dengan konsumsi limbah pertanian $\mathrm{RL} \quad \mathrm{vs} \mathrm{JJ}+\mathrm{JP}+\mathrm{JKT}) . \quad \mathrm{C} 2$, membandingkan antara konsumsi BK dan BO jerami rumput-rumputan (JJ dan JP) dengan jerami legum (JKT), sedangkan C3 adalah membandingkan antara konsumsi BK dan BO antara jerami rumputrumputan (JJ vs JP). Hasil uji lanjut orthogonal kontras $\mathrm{C} 1$ menunjukkan bahwa BK dan BO rumput lapang secara nyata $(\mathrm{P}<0,05)$ dikonsumsi lebih banyak dari pada BK limbah pertanian. Tingginya konsumsi BK dan BO rumput lapang dibandingkan dengan rataan konsumsi jerami padi, jerami jagung dan jerami kacang tanah secara bersamaan dikarenakan rumput lapang diberikan dalam kondisi segar sehingga lebih palatabel dibandingkan jerami jagung, jerami padi, dan jerami kacang tanah. Selain itu limbah pertanian yang berupa jerami bersifat voluminous (bulky) sehingga jumlah konsumsinya rendah karena cepat memenuhi rumen dan cepat mengenyangkan. Hal ini sejalan dengan pendapat van Soest (1994) yang menyatakan bahwa pakan yang bersifat bulky akan cepat memenuhi rumen, oleh karena itu akan dikonsumsi lebih sedikit.

Hasil orthogonal kontras C2 menunjukkan bahwa tidak ada perbedaan yang nyata $(\mathrm{P}>0.05)$ pada konsumsi BK antara kedua kelompok perlakuan tersebut, tetapi hal sebaliknya terjadi pada kontras C2 untuk konsumsi BO dimana konsumsi BO kacang tanah nyata lebih tinggi $(\mathrm{P}<0,05)$ dibanding dengan konsumsi jerami jagung dan jerami padi. Hal ini diduga karena kandungan BO jerami padi sangat rendah $(77,92 \%)$ sehingga mempengaruhi jumlah konsumsi BO jerami rumput-rumputan.

Hasil orthogonal kontras (C3) yang membandingkan antara konsumsi BK dan BO jerami jagung dengan jerami padi, ternyata bahwa tidak ada perbedaan yang nyata $(\mathrm{P}>0.05)$ antara konsumsi $\mathrm{BK}$ jerami jagung dengan jerami padi. Hal ini diduga 
karena jerami yang bersifat bulky/voluminous sehingga cepat memenuhi rumen sehingga ternak merasa cepat kenyang yang berakibat tidak ada perbedaan yang nyata pada jumlah konsumsi BK dari perbandingan di atas. Sebaliknya konsumsi BO jerami jagung nyata lebih tinggi $(\mathrm{P}<0,05)$ dibanding konsumsi BO jerami padi. Hal ini diduga karena rendahnya kandungan BO jerami padi (77,92\%) dibanding jerami jagung $(91,94 \%)$ yang menyebabkan perbedaan ini walaupun tidak ada perbedaan yang nyata pada konsumsi BK antara kedua macam jerami ini.

Pada Tabel 3 dapat dilihat bahwa kecernaan BK pakan perlakuan berada pada kisaran antara 63,51 - 72,78\% dan kecernaan BO berkisar antara 67,33 $78,91 \%$. Analisis keragaman menunjukkan bahwa perlakuan memberikan pengaruh yang berbeda nyata $(\mathrm{P}<0,05)$ terhadap kecernaan BK dan BO. Hasil uji lanjut orthogonal kontras $(\mathrm{C} 1, \mathrm{C} 2$, dan $\mathrm{C} 3)$ pada kecernaan BK dan BO mempunyai trend yang sama. Hasil uji lanjut orthogonal kontras $\mathrm{C} 1$ untuk kecernaan $\mathrm{BK}$ dan $\mathrm{BO}$ menunjukkan bahwa tidak ada perbedaan yang nyata $(\mathrm{P}>0.05)$ pada perbandingan di atas, atau dengan kata lain bahwa rataan kecernaan bahan kering rumput lapang (RL) dibandingkan dengan rataan kecernaan kelompok jerami jagung (JJ), jerami padi (JP), dan jerami kacang tanah
(JKT) secara kelompok relatif sama. Hal ini diduga karena kandungan ADF dari kedua kelompok tersebut relatif sama, dimana kandungan ADF secara berturutturut adalah sebesar 42,93\%, 42,36\%, $52,18 \%$ dan $31,28 \%$. Hal ini sejalan dengan pendapat Van Soest dan Robertson (1985) dan Van Soest (1994) yang menyatakan bahwa salah satu faktor yang menpengaruhi kecernaan adalah kandungan ADF suatu bahan pakan.

Hasil uji lanjut (C2) menunjukkan bahwa kecernaan BK dan BO jerami rumput-rumputan (jerami jagung dan jerami padi) nyata lebih rendah $(\mathrm{P}<0,05)$ dibanding dengan kecernaan BK jerami legum. Begitu pula hasil kontras C3, ternyata kecernaan BK jerami jagung nyata lebih tinggi dibanding jerami padi. Hal ini diduga karena perbedaan kandungan protein; dimana jerami kacang tanah mengandung PK lebih tinggi dibanding jerami jagung dan jerami padi, begitu pula kandungan PK jerami jagung lebih tinggi dari pada jerami padi. Selain faktor PK, komponen dinding sel akan mempengaruhi kecernaan. Kandungan NDF, ADF, selulosa dan hemiselulosa pada legum lebih rendah dibandingkan rumput-rumputan (Pittman dan Moore, 1985; Brown dan Pittman, 1991).

Seperti telah dinyatakan di atas bahwa kandungan ADF sangat mempengaruhi kecernaan, selain itu 
kandungan silika bahan pakan juga mempengaruhi kecernaan Jackson (1977). Silika digunakan sebagai elemen struktural bersama-sama dengan lignin untuk memperkuat dan mengeraskan dinding sel tanaman (Van Soest, 1982). Silika mempunyai efek negatif pada kecernaan rumput-rumputan, dimana terjadi penurunan kecernaan $\mathrm{BK}$ sebesar 3\% setiap kenaikan 1 unit silika (Van Soest and Jones, 1968). Minson (1971) menyatakan bahwa tidak ada efek kandungan silika terhadap kecernaan BO. Van Soest (1970) menunjukkan adanya hubungan negative antara kandungan silika dan lignin hijauan dengan kecernaan, dan penurunan kecernaan lebih erat asosiasinya dengan jumlah lignin dan silika dari pada setiap komponen itu berdiri sendiri. Selanjutnya Van Soest dan Robertson (1985) dan Jackson (1977) menyatakan bahwa kandungan ADF dan silika berbanding terbalik dengan kecernaan, dimana semakin tinggi kandungan kedua nutrien tersebut maka kecernaan akan semakin rendah.

\section{KESIMPULAN}

Berdasarkan hasil penelitian tentang kecernaan bahan kering dan bahan organik pakan berbasis limbah pertanian dan rumput lapang yang disuplementasi dengan urea molasses multinutrient block
(UMMB) pada sapi PO maka dapat disimpulkan bahwa :

1. Rumput lapang menghasilkan kecernaan bahan kering dan bahan organik yang sama dengan jerami limbah pertanian (jerami jagung, jerami padi dan jerami kacang tanah)

2. Kecernaan bahan kering dan bahan organik jerami kacang tanah (legum) lebih baik dari pada kecernaan bahan kering dan bahan organik jerami rumput-rumputan (jerami jagung dan jerami padi).

3. Kecernaan bahan kering dan bahan organik jerami jagung lebih tinggi dibanding kecernaan bahan kering dan bahan organik jerami padi.

\section{DAFTAR PUSTAKA}

Association of Official Analitical Chemist. 1990. Official Methods of Analysis. $115^{\text {th }}$. Ed. Washington D.C.

Brown, W.F., and W.D. Pittman, 1991. Concentration and degradation of nitrogen and fiber fractions in selected tropical grasses and legumes. Trop. Grasslands, 25 : $305-312$.

Chusaemi, S., Soebarinoto dan Sulastri. 1989. Kecernaan dan retensi nitrogen pada kambing yang diberi ransum basal jerami padi dan menir dengan tambahan UMB. Prosiding. Pertemuan Ilmiah Ruminansia Jilid 2. Puslitbangnak. Bogor. Hal 174178. 
Garg, M.R., and B.N. Gupta. 1992. Effect of supplementing urea molasses mineral block lick to straw based diet on DM intake and nutrient utilization. Asian-Australian J. Anim. Sci: 5 (1): 39 - 44

Jackson, M.G. 1977. Review article: the alkali treatment of straws. Anim. Feed Sci. and Technol. 2: $105-$ 130.

Maaruf, K. 1986. Korelasi antara kecernaan in situ dan in vitro serta komposisi kimia limbah pertanian untuk kambing dan domba. Tesis. Fakultas Pascasarjana. Universitas Gadjah Mada, Yogyakarta.

Maaruf, K. dan U. Paputungan. 2017. Comparison of protein and cell wall degradation of selected tropical and temperate roughages. Livestock Research for Rural Development. 29 (6) 2017.

Minson, D.J. 1971. Influence of lignin and silicon on a summstive system for assessing the organic matter digestibility of panicum.Aust.J. Agric. Res. 22: 589-598.

NRC, 1980. Nutrient Requirements of Beef Cattle. National Academy of Science, Washington, DC., USA.

Pittman, W.D. and J.E. Moore, 1985. Monosacharides in detergent residues of tropical forages plants. Crop Sci., 25 : 790 - 792.
Preston, T.R. dan R.A. Leng. 1987. Matching Ruminant Production Sistems with Available Resources in the Tropic and Sub-Tropic. International Colour Production. Stanthorpe, Queensland, Australia.

Utomo, R., S. Reksohadiprodjo, B.P. Widyobroto, Z. Bachrudin and B. Suhartanto. 1998. Determination of nutrients digestibility rumen fermentation parameters, and microbial protein concentration on Onggole crossbred cattle fed rice straw. Bull. of Anim. Sci. Supplement Ed. Faculty of Anim. Sci. Gadjah Mada Unuversity. pp. $82-88$.

Van Soest, P.J. and L.H.P., Jones. 1968. Effect of silica in forages upon digestibility. J. Dairy Sci, 51: 1644

Van Soest, P. J. and J.B. Robertson. 1985. Analysis of Forages and Fibrous Foods. A Laboratory Manual for Animal Science 613. Cornell University.

Van Soest, P.J. 1970. The role of silicon in the nutrition of plants and animals.In proc. Cornell Nutrition Conference.

Van Soest, P. J. 1994. Nutritional Ecology of Ruminant. O \& B Books. Corvallis, OR. 